\title{
Religious language as natural-sacred language ${ }^{\star}$
}

\section{Massoud Toossi Saeidi ${ }^{1}$, Seyed Hassan Hossini ${ }^{2}$}

${ }^{1}$ Institution for Humanities and Cultural Studies, $64^{\text {th }}$ St., Tehran, Islamic Republic of Iran, 14377-74681

${ }^{2}$ Sharif University of Technology, Azadi Ave, Tehran, Islamic Republic of Iran, 11365-11155

For citation: Massoud Toossi Saeidi, Seyed Hassan Hossini. Religious language as natural-sacred language. Vestnik of Saint Petersburg University. Philosophy and Conflict Studies, 2021, vol. 37, issue 1, pp. 176-190. https://doi.org/10.21638/spbu17.2021.114

The article offers a different interpretation of Antony Flew's views about the problem of religious language. This interpretation shows that Flew's ideas can be perceived as a critique of belief in the content of religious statements, rather than a critique of their meaning. By interpreting his thought in this way, it is clear that Flew's approach is not new and we can find similar ideas in the history of theological thought. In connection with this interpretation, the authors analyze prevalent theories related to this problem in order to identify the principal doctrines used to find a new solution. In this regard, the new potential solution is assessed in order to complete the approach previously undertaken. The main idea is to merge two distinct and also contrasting concepts found in the literature: "natural" and "sacred". Such a merging can begin with the concept of natural language as a theory drawn from the literature on the philosophy of language. According to the principles of the philosophy of language adopted by this article, religious language is rooted in natural language, but it is distinct from other forms in that it is the customized use of natural language by the saints of a particular religion. By offering an explanation to natural language, it is possible to view saints as the ones who used natural language in order to talk about the divine sacred realm. Similar to previous thinkers who spoke about religious language, the authors offer their own analogy. This analogy is compared and contrasted with previous ones to reveal the advantages of the proposed new view of the problem of religious language. The authors propose a new type of natural language with the special characteristic of being sacred.

Keywords: religious language, sacred knowledge, natural language, saints, natural-sacred language.

\section{Introduction}

After putting an end to five decades of atheistic practices, Antony Garrard Newton Flew contended that his interests about religious language had been wrongly understood from the beginning [1, p. XI]. In addition to this radical turn of Flew, William Alston begins his article on religious language by writing that religious language does not qualify as a suitable name to designate a set of philosophic problems and concerns [2, p. 234-235]. Such remarks from representatives of two distinct intellectual traditions, as well as the recent decline in discussions on religious language, lead us to the idea that there is an eclipse

* The research was made possible due to a grant from the Iran National Science Foundation (INSF).

(C) St. Petersburg State University, 2021 
in this area. However, perhaps a reinterpretation of the problem of religious language reveals the hitherto hidden aspects of the problem and, instead of abandoning these efforts, it might enable us to improve this line of analysis - knowing the fact that the problem of religious language was the most vibrant issue in the circles of philosophy of religion during the latter half of the twentieth century.

The importance of this claim could be clearer if we note that the main question how can one speak about a sacred entity that transcends this material world just by utilizing natural mundane language? - has been constantly mulled over by philosophers and theologians alike. To put it in simple words, if we consider the writings of Thomas Aquinas and his doctrine of analogy as an effort to deal with the problem of religious language, then it is possible to understand how old and complex the history of this problem is [3, p. 14-31]. Therefore, we think that proposing a reinterpretation of the problem of religious language can be a fruitful philosophical practice.

In short, the decline in debates surrounding the problem of religious language can be seen as an opportunity to review previous efforts and theorize new approaches to solve it. To make use of this opportunity, we should first explore previous efforts and research in detail in order to sketch an accurate picture of the problem at hand and then, by using useful doctrines of past philosophers, we can theorize a new possible answer. At the end of this route, important implications of this new answer would be analyzed.

\section{Reinterpretation of the problem of religious language}

After ceasing five decades of atheistic practice, Antony Flew made it clear that his influential theory on religious language, which gave rise to many subsequent debates during the latter half of $20^{\text {th }}$ century, was misunderstood:

Although my intention in raising these questions seems clear, I have repeatedly encountered claims that I was expounding my views about the meaning - or more often the meaninglessness - of all religious language. Just as prevalent have been claims that I was explicitly appealing to (or at least taking for granted) and relying upon the notorious verification principle of the old original Vienna Circle of logical positivists - that only statements that could be verified using the methods of the sciences were meaningful.

But in fact, I have never maintained any comprehensive thesis about the meaning or the meaninglessness of all religious language. My primary purpose in "Theology and Falsification" was to spice up the bland dialogue between logical positivism and the Christian religion and to set discussion between belief and unbelief upon different and more fruitful lines. I was not offering any comprehensive doctrine about all religious belief or all religious language. I was not saying that statements of religious belief were meaningless. I simply challenged religious believers to explain how their statements are to be understood, especially in the light of conflicting data $[1, \mathrm{p} .44]$.

If one accepts these claims, then it is clear that for about fifty years, Flew's concern about religious language was misunderstood. Given new clarifications made by Flew, it is necessary to reconsider the problem. A review of the reactions to Flew's ideas reveals that many interpret Flew's claims in line with meaningfulness criterion in the logical positivism context. We can see these reactions clearly illustrated in parables such as Hare's 
"Parable of Crazy Student"1 [4, p. 100], Mitchell's "Parable of the Partisan"2 [4, p. 103], John Hick's "Parable of Celestial City" and "Eschatological Verification"3 [5, p. 94-105], and Plantinga's ideas and Yandell's illustration of Plantinga's ideas in the form of "Parable of Inquisition Execution"4 [6, p. 156-187; 7, p. 13]. As it is obvious from these reactions, Flew's concern has been understood as a linguistic issue that regards falsifiability as a meaningfulness criterion and claims that religious statements are meaningless because they cannot be falsified.

Despite this interpretation of Flew, we claim that Flew's approach is not purely linguistic in terms of logical positivism. In other words, his ideas can be fathomed without reliance on the philosophy of language or doctrines associated with Russell, First Wittgenstein, Vienna Circle, Popper, and others. Flew uses a parable, extracted from a tale told by John Wisdom in his article "Gods", to explain his idea about Religious Language:

Once upon a time, two explorers came upon a clearing in the jungle. In the clearing were growing many flowers and many weeds. One explorer says, 'Some gardener must tend this plot'. The other disagrees, 'There is no gardener'. So they pitch their tents and set a watch. No gardener is ever seen. 'But perhaps he is an invisible gardener'. So they set up a barbed-wire fence. They electrify it. They patrol with bloodhounds. (For they remember how H. G. Wells's The Invisible Man could be both smelt and touched though he could not be seen.) But no shrieks ever suggest that some intruder has received a shock. No movements of the wire ever betray an invisible climber. The bloodhounds never give a cry. Yet still, the Believer is not convinced. 'But there is a gardener, invisible, intangible, insensible to electric shocks, a gardener who has no scent and

${ }^{1}$ A pessimist student at the University of Oxford, who is frenetic, thinks that all professors are trying to kill him, and various pieces of evidence he observes every day against his mental presupposition is interpreted by him in a way that is consistent with his hypothesis. For example, the kindnesses of professors are considered as deceptive behavior. By using this parable, Hare claims that even though this student rejects pieces of evidence which falsify his belief, his belief is meaningful.

${ }^{2}$ A partisan, during worship, meets a stranger who claims that "I am the leader of the resistance movement". The stranger urges the partisan to have faith in him, even if he is seen to be acting against partisan interests. The partisan commits to this idea but his friends think he is a fool to do so. The first encounter with the stranger gives the partisan sufficient confidence to hold onto his faith in him even when there is evidence against it. This belief, finally, can be falsified or verified after the end of the war, but not before it. Mitchell uses this parable to illustrate the independence of the meaningfulness form falsifiability/verifiability, especially in the case of non-propositional faith - such as trust in God which may be meaningful even when there are pieces of evidence against it.

${ }^{3}$ In Hick's parable of "Celestial City", two people are travelling along a road. One believes that the road leads to a celestial city; the other believes that it leads to nowhere. With respect to their presupposition, they interpret events differently but only at the end of the road it will be clear who is right. So their beliefs could be falsified or verified, but not when they are on the road. By using this parable, Hick says that a proposition such as "there is an afterlife" can be verified but not falsified (if it is false, the individual will not know because no one would be alive to know). This situation is most common in propositions regarding God and the afterlife - although this can be applied to other propositions like moral ones - which can be verified only after death. Hick names this kind of verification "Eschatological", which means a proposition can be verified but after death. Therefore, even if we use verifiability as the meaningfulness criterion, these propositions are meaningful.

${ }^{4}$ Plantinga, with respect to his linguistic understanding of Flew's parable, claims that anything which counts against an assertion must be a part of the meaning of the negation of that assertion. And this leads to very bizarre consequences. Keith Yandell uses the assertion "Flew exists" to make Plantinga's point clear. As a result of Flew's position, part of the meaning of "Flew exists" is the fact that "Flew was never devoured by a dinosaur" and "Flew was not executed by the inquisition" also counts against "Flew exists" and therefore is part of the meaning of the negation of it - i. e. "Flew does not exist". The point is that there appear to be infinite different propositions that count against Flew's existence! See: [8, p. 33]. 
makes no sound, a gardener who comes secretly to look after the garden which he loves.' At last, the Sceptic despairs, 'But what remains of our original assertion? Just how does what you call an invisible, intangible, eternally elusive gardener differ from an imaginary gardener or even from no gardener at all?' [4].

In spite of understanding this parable in a positivistic context, it seems that Flew emphasizes "Persuasion" or "dogma" instead of meaningfulness criterion. For Flew, it appears that the believer would insist on their beliefs at any cost. Flew emphasizes that the community of believers do not let their faith be assessed and tested and, ever their beliefs are at risk in a situation of contrary pieces of evidence, they somehow escape from being falsified. This is what makes Flew suspicious of the believers' understanding of the content of religious statements because he thinks that for believers, keeping a formal version of their faith is more important than the content of their faith. This also is the reason why he distinguishes his view from that of positivists and Popper.

There is no doubt that persuasion is prevalent among the believers in any religious community. However, it might have nothing to do with the meaningfulness of religious statements, rather it might relate to believers' understanding of religious statements. The importance of the understanding of religious language is clear even in Flew's own parable. Because the drawback of falsifiability, which Flew maintains that religious statements suffer from, is all grounded on Flew's inadequate concept of God. If one conceives God as the gardener taking care of a garden (as it is illustrated in the parable of the "Explorers and Indivisible Gardener"), who only facilitates a natural procedure, it is obvious that the existence and non-existence of this God do not matter significantly. But on the contrary, if one accounts for the whole procedure of growing plants, in terms of a constant discipline (i. e. Natural Laws), prescribed by God who is continuously allowing this discipline to be effective and valid, the whole picture would change dramatically. Unfortunately, the responses of Hare, Mitchell, Hick and Plantinga to the problem of religious language are offered with a misguided approach, which lacks proper attention to the important role of the concept of God ${ }^{5}$.

If understood in the light of paying attention to the concept of God, Flew's parable can be rendered as a critique of belief in the content of religious statements, rather than a critique of their meaningfulness. By interpreting this parable in this manner, it is clear that Flew's concern is not a new one and we can find similar concerns in the history of theological thought. Therefore, the reinterpretation of Flew's concern about the problem of religious language entails that we should not concentrate on the meaningfulness of religious statements. Instead, we should understand the problem as a challenge of talking about the deity, a completely transcendent realm of existence from the natural world, with a man-made language.

\section{Analyzing theories of religious language}

During the flourishing period of the latter half of $20^{\text {th }}$ century, with the decline of logical positivism, many theories were developed regarding religious language that can be placed into two major groups: ideas associated with the Oxford school and ideas associ-

${ }^{5}$ This analysis originally belongs to Hamidreza Ayatollahy, emeritus professor of philosophy and head of IAPR (Iranian Association for Philosophy of Religion). I acquired it from him at a lecture at the $2^{\text {nd }}$ International Conference on Contemporary Philosophy of Religion. 
ated with the Cambridge school. The latter school consisted of thinkers who posit a formal conception of meaning as the basic approach to the philosophy of language. In other words, they believe that language can be incorporated into formal logic. These thinkers included Russell and Wittgenstein in his early writings. On the other hand, the Oxford school believed that meaning is not determined, and the formal structure of logic cannot explain the meaning. They regarded meaning as a function of Ordinary Language. Austin and Wittgenstein in his later period were among the chief members of this school.

A review of these two schools' ideas implies that Cambridge thinkers tended to focus more on questioning the meaningfulness criterion of religious statements, while Oxford thinkers took meaningfulness for granted. Therefore, with respect to previous clarifications, our approach in this work conforms to the latter group more than the former.

The Oxford school itself had two sets of ideas: on the one hand, some theories regarded religious statements as statements with epistemic content and, on the other hand, some other theories reject that religious statements have such content [3, p. 67-79]. These latter thinkers, for example, claim that religious statements have an ethical role in society as well as provoking and symbolical, and not an epistemic role in describing the realm of deity.

This duality is also significant because: (1) Believers initially tend to value religious statements as far as they are realistically epistemological; "the vast majority of religious adherents are religious realists" [9] and (2) Flew's comments, with respect to our interpretation, is also a focus on this tendency (i. e. epistemic content of religious statements) ${ }^{6}$. As a result, those theories which regard religious statement as both meaningful and having epistemic content, are preferred in regard to the new interpretation of the problem.

An analytical review of the existing theories of religious language and following those associated with the Oxford school, giving priority to those who admit that religious statements have epistemic content, the following doctrines would be deduced:

1. Religious experience is the source of epistemic content of religious statements. Most of the theories which endorse that religious statements have epistemic content tend to resort to religious experience as the ultimate source of meaning. Alston [10], Crombie [11], Wisdom [12] and Ramsey [13, p. 20-21] are among the theorists who have somehow defended the epistemic content of religious statements. These four thinkers shared the view that the epistemic content of religious statements is rooted in religious experience and these experiences are mediated through religious language. In other words, these experiences are epiphanic - therefore they have epistemic content - and religious language is, in fact, a medium to express them. Alston explicitly claims that the truth of religious statements depends firmly on religious experiences as much as the truth of scientific statements depends on sensory experiences [10].

2. Religious statements create liability in believers and make them responsible. The content of religious statements somehow concerns the fate of the audience, it makes them care about and become attached to these statements. This state of care is evident in parables put forward by Hare, Mitchell, and Hick mentioned above. The liability created by these statements exceeds that evoked by ethics to the extent that Braithwaite, despite his intention to reduce religious statements to

${ }^{6}$ If religious statements do not have any epistemic content, then their verifiability and falsifiability are meaningless themselves! 
ethical statements, admitted the greater psychological force of these statements compared with ethical ones [14, p.16-27]. He says, "the intention of a Christian to follow a Christian way of life... is the criterion for the meaningfulness of his assertions" [14, p. 16]. Such liability is also present in the ideas of Tillich [15, p. 1112] and Ramsey [13, p. 39].

3. Ecumenical hierarchy in a religious community has a paramount role in shaping the epistemic content of religious statements. Ramsey was the first who suggested that religious language is unique because it employs "common models of natural language" along with "descriptors" that enables it to talk about religious experiences and external reality, perceived by such experience, as much as possible [13, p. 69-90]. His idea, however, was unable to distinguish suitable models and descriptors from non-suitable ones. In an effort to meet this requirement, Soskice recommended that interpretative tradition in a religious community should be the criterion for distinguishing proper from improper statements [16, p.147]. This view implies realism in regard to religion and has attracted some advocates in other linguistics debates, such as debates around scientific language [17, p. 173-189].

4. The presupposition of a God-Universe relationship has a crucial role in the meaning of religious statements. John Hick, after admitting what Wilfred Cantwell Smith claimed in his book The Meaning and End of Religion, believes that when religious studies are viewed from a high perspective, it becomes clear that previous intellectual systems, including theology, revolved around the concept of God whereas current debates in philosophy of religion and theology have replaced "God" with "religion". He argues that such a view of religion is the result of the dominance of approaches such as empiricism, naturalism, and positivism which are the warp and woof of contemporary philosophy [5, p. 112-113]. This unsavory shift has led to the relegation of the concept of God (including the proof of the existence of God and various conceptions of God) into a peripheral or inferior position beside other issues like religious language. This condition bars philosophical debates from exploring and understanding the effects of philosophical presuppositions about God in issues such as religious language. However, as Ayatollahy points out in his discussion of religious language, the relationship between God and universe directly influences our perception of meaningfulness, semantics, and epistemic content of religious language as well as of other important theological issues like the Problem of Evil [18, p. 14-18]. Regarding God as the universal gardener, as a celestial father, or as an omnipresent entity, plays an important role in shaping our interpretation of religious language.

5. Being a literalist concerning religious statements makes their epistemic content susceptible to being misunderstood. As Stiver argues, a negative approach toward some statements and considering them as unreal, such those containing a metaphor, analogy, symbol, and similar figures of speech, and regarding them as lacking epistemic content is a direct legacy of the Aristotelian tradition in the history of philosophy [3, p.9-11,113-121]. If we could somehow get rid of such presuppositions, we could free up much space for understanding and appreciating religious texts. This can be accounted for by the fact that if nondescriptive statements are regarded as having no epistemic content, in the sense 
that epistemic content lies only in descriptive statements, then those religious statements containing symbolic and metaphoric elements lose their epistemic content. However, if the epistemic value is not pinned only to descriptive statements, according to some threads in the practice of philosophy of language, then symbolical, analogical, and metaphorical statements can also be regarded as bearers of truth. Accordingly, a vast space would be available to explore the meaningfulness of religious statements.

In this work, we accept all of these five points. Organizing and consolidating these points into one doctrine, are in principle possible, in a philosophical investigation of language. In other words, the fruits of analyzing the views of religious language and giving priority to the Oxford school should be organized into a single philosophy of language doctrine. Expounded upon below, this basis is used as a philosophical stage for theorizing about religious language.

\section{Proposing a philosophical basis for religious language}

Any solution for the problem of religious language must necessarily be built on a base of the philosophy of language. Here, we build our approach toward this problem on views associated with the Oxford school which were described above. It should be noted that the ideas of Wittgenstein, as proposed in his 'language games' in his latter philosophy, are the chief inspiration for views associated with the Oxford school.

Wittgenstein constantly insisted in his later period on what is called "Back to the rough ground." In Philosophical Investigations, he asserted that language should be assessed in the way it is ordinarily used. As a result, using such categories as symbol and metaphor is a valid practice in language [3, p. 112-134]. When language is evaluated in the way it is used, then we must count meaningful anything that is traditionally and commonly regarded as meaningful. Language is invariably used by members of a community and is dynamic and meaningful, and all language variations are therefore admitted. This is called the theory of ordinary language, which is the inspiration for much theorizing in the philosophy of language.

As we know, Wittgenstein, Austin, and others are regarded as philosophers of ordinary language and they were not primarily concerned with the problem of religious language. Nevertheless, Seyyed Hassan Hosseini has drawn from these philosophers and developed a customized version of the ordinary language doctrine for religious language, especially in regard to the conformity of his views with accepting epistemic content for religious statements. The present work has employed Hosseini's natural language doctrines - his re-configuration of ordinary language - with minor alterations.

$\mathrm{He}$ articulates his theory of natural language with the following six features [19, p. 94-97]:

1. Meaningfulness is multifaceted and multidirectional. Meaningfulness has many criteria in the philosophy of language. Each theory, referential or ideational for example, has its own distinctive criteria in this regard and, similarly, natural language proposes its own definition of meaningfulness. However, despite its distinctive features, Hosseini wants to incorporate the merits of previous criteria in his own view. For example, natural language sometimes uses referential criterion 
(e. g., in scientific applications) and sometimes uses ideational criterion (e. g., in poetic uses of language). In short, natural language does not limit itself to some fixed criteria and it follows other theories whenever useful. According to the theory of natural language, these different criteria are actually fruits of induction from various ordinary language usages. Therefore, one can extend this theory according to new language usages in novel situations.

2. Meaningfulness changes constantly. Given the significant role of language usage in determining meaning, meaningfulness of language units - including words and statements - is volatile and changes depending on the specific use of those units. This does not mean that language conventions do not have any role. Rather, this is to say that meaningfulness is dynamically changing according to different language conventions.

3. Meaningfulness cannot be reduced to descriptive propositions. Language units play various roles, and their usage is not limited just to descriptive ones. They can be utilized in various situations and play various roles: serving as a metaphor, symbol, synecdoche, or something else. Meaningfulness, in these applications, is therefore dependent on the usage and on the interpretation. In addition, distinctions such as descriptive and non-descriptive ones, contribute to the meaningfulness but they do not determine the meaning independent of the audience and other factors.

4. Meaningfulness and verification are distinct. Unlike the insistence of logical positivists on verification as the sole criterion of meaningfulness, natural language regards verification as secondary for the meaningfulness of language units.

5. Verification of truth and falsity comes from a variety of epistemic sources: in natural language, verification of the statements is in line with the epistemic sources. According to the multiplicity of these sources, verification can be settled by experience, ratiocination, speculation, intuition, religious experience, and revelation. Each expression must be assessed and verified with respect to its source of epiphany.

6. Natural language is the shared aspect of unnatural languages. Un-natural languages such as scientific language or religious language, are rooted in natural language although they are characterized by their particular language usages. As a result, it is not possible to fully distinguish unnatural languages from each other, even though they have their own special aspects. This, however, does not mean that natural language is the total sum of unnatural languages. Rather, it means that any unnatural language is assigned a unique character through natural language.

Hosseini believes that religious language is just natural language. He explains the various approaches to religion based on a $2 \times 2$ matrix with "ontological" and "epistemological" in its rows, and "realism" and "anti-realism" in its columns. He adheres to the belief that religion, from an internal religious logical point of view, would be realistic both ontologically and epistemologically while also claiming that natural language of religion is soundly congruent with these philosophical principles and is consequently accepted by the community of believers.

In this study, we accept natural language as the customized basis of the philosophy of language for the problem of religious language and try to explain its special aspect. We 
think that religious language is characterized by some property that distinguishes it from a pure natural language (as formalized above by Hosseini) in the community of believers. That special property is the very sacrosanctity of religious language and religious statements. In other words, in a linguistic game played by a religious community, it assumes that such statements harbor sacred knowledge, a property that distinguishes religious language from the language of poetry or that of science [20, p. 255-272] and these forms also have their own properties which distinguish them from being a mere natural language.

It should be noted that natural language is not sacrilegious, so it could be characterized by sacrosanctity. For instance, the name of one's birthplace could be so highly honorable and respectable in natural language that any failure to respect that would lead to displeasure and hard feelings. But the sacrosanctity of religious language among the religious community goes beyond that. The sacrosanctity of religious language is due to the fact that this language deals with sacred issues that transcend this world and its ordinary categories. It seems that the liability of a religious statement, according to the teachings of the extant theories, is rooted in this very sacrosanctity.

Therefore, assigning this lofty sacrosanctity to religious language completes the theory of natural language. At the same time, it appears that being natural and being very sacrosanct simultaneously, is somehow a paradox in regard to modern thought. The present study postulates the notion of saints of religion as the sole origin of religious statement in order to explain how sacred knowledge is gleaned from natural religious statements. In fact, the present study follows Soskice in recommending realism in connections with traditions of the religious community [16, p. 108-115], but with a slight difference: whereas he concentrates on tradition and the model of interpretation in a religious community, the present study stresses the central role played by saints of religion, as special persons, in meaningfulness and the interpretation of religious statements.

\section{Saints of religion and religious language}

From a believer's point of view, categories such as 'God,' 'Holy Texts', etc., along with the category of 'Saints', form a coherent whole in which each category has its own importance in terms of a believer's system of beliefs. However, looking at the discussions in contemporary philosophy of religion reveals that there is no independent discussion or debate as well as other intellectual practice that is exclusive to 'Saints'.

In this work, 'Saints' is understood as those who are eminent persons that: a) can convince their audience that they are inspired with or linked to divinity and b) can convey teachings from sacred truths of divine realms. This category is known as 'prophet', 'messenger' and etc. in Abrahamic religions of Judaism and Islam whereas in Christianity, the figure of Jesus as 'God the Son' (following the doctrine of incarnation) and 'apostles', 'saints' etc. fulfill the same role. In this article consequently, we use the term 'saints' in an extended way with respect to its ordinary usage and historical individuals.

Ghafari, by analyzing a case study of Avicenna, shows that a review of the classical intellectual discussions on Abrahamic religions reveals that previous debates revolved around the category of 'Saints' more robustly than the contemporary philosophy of religion do [21, p. 62]. The significance of saints of religion in the problem of religious language becomes even more pronounced when we realize that most of the religious texts and sacred books are in fact collections of sayings and teachings of saints. 
Nonetheless, introducing 'Saints' into the current discussions requires a solid justification since it has been commonly underrepresented in the philosophy of religion literature. But it seems that even if we choose to evaluate religion from a secondary point of view, rather than from the believers' point of view or from an internal religious perspective, we will still find that the category of saints in religion, as some authorities in the religious community especially for religious or sacred knowledge, is worthy of being discussed and explored in religious studies.

It is also possible to claim that it seems all epistemic disciplines emergent in social contexts possess some epistemic authority. In other words, as Alston also has defended in his "Religious Experience and Religious Belief" and also in his Perceiving God, justification of a belief somehow depends on the belief-forming "process" [22; 10, p. 72]. This "process", shaped by a certain portion of society, enjoys a special position that determines the beliefs held by the majority. We emphasize here, in accordance with the scientists who enjoy eminence in the scientific community, that saints also possess a position of authority in spiritual and epistemic matters of religious knowledge within a religious community.

Using the category of 'saints', as defined here and extended in respect to standard usage of this term, is not without precedent in the philosophy of religion. John Hick, an eminent contemporary philosopher of religion, explicitly points out that 'incarnation' is a kind of resolution for the problem of religious language [5, p. 82-83]. According to philosophical criteria, using this special Christian doctrine is not fully reliable as it is an entirely internal religious category, yet it is possible to use a more abstract implication of this doctrine as far as it does not turn the discussion into examining one religious tradition and also does not contradict the approach of the philosophy of religion. In fact, this introduction of the doctrine of the incarnation of Jesus Christ into the philosophy of religion by Hick implies that saints of religion, as we define here, and their positions, corresponding to what has been previously said, could be very important to the philosophy of religion.

It is the saints of religion that specify the religious and non- religious knowledge. This authority inside the community of the believers is established by virtue of the fact that saints of religion are linked with divine realms. In simple terms, although all believers are linked with divine realms to various degrees, the best and noblest form of man-deity connection belongs to saints of religion. Belief in this connection is so important that its acknowledgement appears even as a necessary condition of faith in Abrahamic religions. Connection with divine realms grants saints of religion a sacred status. This relationship is manifested in the religious experience and spiritual states exclusive to the saints of religion. To put it differently, the highest form of religious experience and spirituality in a given community of believers belongs to saints of religion and lets them realize the sacred truths of the divine realms, a fact that makes religious statements attributed to saints of religion highly epiphanic.

Regarding the semantics of religious statements, it is obvious that saints have a special role for interpreting religious statements since their perceptions surpass those of other believers and they are the sole origin of the statements. In fact, the interpretation hierarchy in a religious community would be determined by the hierarchy existing in religious experience.

In short, the present article, emphasize the role of saints in the problem of religious language that includes the following shortened items: 
1. Saints of religion are figures with the noblest relation to the divine realm. This privilege grants saints an epistemic authority on truths of the divine realms.

2. Religious Statements are the expressions and utterances made by saints. Religious statements are generally made by or attributed to saints of religion. The epistemic content of such statements depends on the religious experience of saints. Inspired from an epistemology defended by Alston, as a scientist expresses his scientific opinions which are based on his sensory observations in a laboratory and which are informative, similarly, saints express religious statements on truths of the divine realms based on their religious experience. As a result, religious statements are distinct in that they are the words of those with access to sacred knowledge via their connection with divine realms. Religious statements are natural language in its root. On the one hand, religious statements are just like other utterances common among the individuals and on the other hand, religious statements are sacred and stand above these other utterances since they are produced by those who can experience the noblest religious truths.

3. There is an interpretation hierarchy, in a religious community, with a high authority for saints in it. The semantics of religious statements could be ultimately determined by saints of religion. Just as a scientist or poet surpasses others in explaining his point or intention, saints of a religion can interpret their teachings better than anyone else. As a result, the interpretation hierarchies in a religious community are necessary and closely follow the hierarchies in terms of religious experience.

Therefore, according to the principle of the philosophy of language adopted by this study, religious language is rooted in natural language, but distinct from other forms in that it is the customized use of natural language by saints of religion. The extent that saints have access to the truths of divine realms and also the validity of their teachings accord with those truths, are simply irrelevant in this study. That is because we are dealing with the problem of religious language and not with problems such as religious experience and religious epistemology. Regarding the philosophical presuppositions about the GodUniverse relationship, by the idea proposed by this study, these issues also will be connected to the problem of religious language. After reinterpreting the problem of religious language and trying to prepare a new answer for it by analyzing the literature of this issue, it is revealed that this problem has some important connection with other famous topics of contemporary philosophy of religion, such as religious experience, religious epistemology and concepts of God.

\section{Analogy}

During the second half of the previous century, Flew popularized the problem of religious language by reformulating 'the parable of the invisible gardener'. After this and in reaction to his analogy, various analogies were put forward by Hare, Mitchell, Hick, Yandell, etc., which is mentioned above.

We also wish to propose our own analogy for the same purpose. Adapting and comparing this analogy with the previous ones is helpful as it clarifies the differences and advantages of this new view to the problem of religious language. This analogy also imagines 
world explorers (the same as Flew's), but those whose conflict over a plot does not distract them from their original purpose:

A group of world travelers decide to explore the world in a scientific-recreational journey. There is only one member whose sensory and cognitive faculties are completely sound. Others, however, suffer from some deficiency: one has hearing problems, another olfactory problems, another suffers from a gustatory deficiency, and another has difficulty seeing properly. As a result, they choose the healthy member as their guide.

Once on their way, many incidents befall them and introduce them to various experiences. During these events and experiences, the members rely on the sound member's account and guidance and follow his lead. Sometimes, there is beautiful scenery but the visually challenged member cannot appreciate it. Thus, he must rely on descriptions made by the sound member. Sometimes, there is a pleasant melody in the air but the member with impaired hearing cannot appreciate these sounds. Thus, he must rely on a description of the melody expressed by the sound member.

This sound member, however, faces some challenges. The root cause of all problems lies in the fact that he perceives correctly while others' perceptions are inadequate. He can see but some cannot; he can hear but some cannot. There are times that the leader warns about a pitfall on the way and orders caution, but the unsound member(s) fails to correctly understand the leader's warning or ignores it entirely and so, he falls into the pitfall. The leader sometimes has a hard time convincing the member with the smelling condition about the quality of a scent.

During their journey, there are times when the sound member must stop the group in order to move on independently and perceive and appreciate the conditions that are unfathomable to others since travelling requires complete health. There is a dark cave, for instance, that requires strong eyesight for seeing the path, strong smell for sensing toxic fumes and strong hearing for the sound of dangerous beasts. After rejoining the group, the leader provides them an account of his observations. However, members understand the leader only partially and fail to fully grasp what the leader has witnessed. He may even be criticized and asked: 'what is this nonsense you are telling us?' In fact, the members cannot directly perceive his experience and their weaknesses also have partially obliterated their previous observations and insight. As such, they cannot be convinced about leader's observations and regard his sayings as empty and nonsensical, as hollow effusions of a crazy bard rather than empirical and valid intuitions.

Nonetheless, the leader has some trustworthy mates who firmly believe his remarks. They value the teachings of the leader over their own observations and they can assimilate their understandings to his as well as compare their description to his.

\section{Final points and conclusion}

William Alston begins his essay in The Oxford Handbook of Philosophy of Religion by stating that religious language is a misnomer in addressing some issues in the philosophy of religion. Alston demonstrates his point by asking a clever question: 'Do you speak in English, French or Religious language?!' [2, p.234]. He believes that such a misunderstanding is the result of the wrong tendency in distinguishing between 'language' and 'speech': the former is an abstract system that (per se) is used to communicate whereas the latter is the actual application and usage of the former. Religious language refers to the use 
of language for religious messages which encompass a vast spectrum of contents: from the statements on prayer and worship to moralities, canonical instructions and ontological statements about divine realms.

In line with Alston's subtle points, and by limiting the spectrum to the ontological statements about divine realms, the present article concludes that religious language is the use of natural language by saints of religion or the language of saints of religion. In this article, the epistemic content of religious statements is sometimes compared to the epistemic content of scientific statements, but some points should be clarified here. Regarding the sense experience, some may contend that all individuals have equal access to external reality whereas this is not true in the case of religious experience. In fact, this could not disqualify religious experiences. Alston offers a detailed account of the differences between sense experience and religious experience, and demonstrates that the differences cannot negate the epistemic content of religious experiences [10]. This also shows that one of the other philosophical topics which could have a role concerning the problem of religious language is religious experience. Our understanding of religious experiences could change the results of the acceptance of the theory proposed in this article. For example, if we believe that mystical experiences are the same core of religious experiences in all religious cultures, then this theory may not result in a hard version of pluralism. But if we do not believe that there is a shared core for religious experiences in varieties of religious cultures, then this theory would result in a hard version of pluralism, fideism or exclusivism.

This article emphasizes the authoritative character of saints, which distinguishes them from others in a religious community. In our parable above, not everybody who claims to have seen something is capable of providing an authoritative description. For example, the claimer must have actually experienced that thing with a healthy set of cognitive faculties. Or he must be fully attentive when describing his observations. When such requirements are met, we could accept the belief-forming process as justified and his account of that thing is convincing and revelatory even to one that has some deficiency in his cognitive faculties. This person does not doubt the validity of such statements and achieves some knowledge in spite of not having needed perceptive faculties for direct perception.

Therefore, by the introduction of saints into the philosophical debates around religious language, a new horizon opens up for investigating meaningfulness, semantics, and the epistemic content of the statements about God.

It cannot be denied that, however, religious statements differ from, say, scientific statements. This is the very point that Flew emphasizes in his analogy. According to this article, the difference refers to the intense resistance of the believers against the rejection of the religious statements. Inspired from some scholars, religious statements concern the fate of the audience, elicits concern pushes them toward "persuasion", see: [3, p. 80-84].

Persuasion is defined as the firm faith that is not abandoned easily. This is in line with the liability of religious statements which is rooted in their sacred content. When a believer expresses his belief, his statement implies his intention to act according to that belief. Obviously, the more effective and liable a belief is, the more resistance is shown in face of rejection of that belief. As shown in this study, resistance does not threaten meaningfulness, epistemic content, and rationality of religious statements.

Finally, it should be noted that the approach proposed by this study for addressing the problem of religious language introduces some rational duties for the believer. It is easy for anyone to claim that he is a saint, and start telling some sacred fictions, just the same as it 
is easy to claim to be a novel scientist who discovers many secrets of nature. Consequently, any believer who wants to believe in a sacred story, told by a saint candidate, must use rational criteria in order to evaluate claims and the claimer. This also could lead to certain limitations on pluralism. In other words, any saint candidate, belief-forming process and religious system of belief, could (and should) be compared with others by rational criteria.

\section{References}

1. Flew, A. and Varghese, R. A. (2008), There Is a God: How the World's Most Notorious Atheist Changed His Mind, New York: Harper One.

2. Alston, W. P. (2005), Religious Language, in Wainwright, W. J. (ed.), The Oxford Handbook of Philosophy of Religion, Oxford: Oxford University Press, pp. 234-242.

3. Stiver, D. R. (1996), The Philosophy of Religious Language: Sign, Symbol and Story, Cambridge, Mass., USA: Blackwell Publishers.

4. Flew, A., Hare, R. M. and Mitchell, B. (1964), Theology and Falsification: The University Discussion, in Flew, A. (ed.), New Essays in Philosophical Theology, New York: Macmillan.

5. Hick, J.H. (1989), Philosophy of Religion, $4^{\text {th }}$ ed., Englewood Cliffs, N. J.: Pearson.

6. Plantinga, A. (1990), God and Other Minds: A Study of the Rational Justification of Belief in God, Ithaca: Cornell University Press.

7. Yandell, K.E. (1971), Basic issues in the philosophy of religion, Boston: Allyn and Bacon.

8. Harris, J. F. (2013), Analytic Philosophy of Religion, Berlin, Heidelberg: Springer Science and Business Media.

9. Meister, C. (2018), Philosophy of Religion, in The Internet Encyclopedia of Philosophy (IEP). Available at: https://www.iep.utm.edu/religion/H1m (accessed: 01.02.2020).

10. Alston, W. P. (1986), Perceiving God, The Journal of Philosophy, vol. 83, no. 11, pp. 655-665.

11. Crombie, I.M. (1955), Theology and Falsification, in New Essays in Philosophical Theology, New York: Macmillan, pp. 109-30.

12. Wisdom, J. (1944), Gods, Proceedings of the Aristotelian Society, vol. 45, pp. 185-206.

13. Ramsey, I. T. (1963), Religious Language an Empirical Placing of Theological PhrasesI, New York: Macmillan.

14. Braithwaite, R. B. (1955), An Empiricist's View of the Nature of Religious Belief, Cambridge: Cambridge University Press.

15. Tillich, P. (1973), Systematic Theology, vol. 1, Princeton, N. J.: University of Chicago Press.

16. Soskice, J. M. (1987), Metaphor and Religious Language, Oxford: Clarendon Press.

17. Godfrey-Smith, P. (2009), Theory and Reality: An Introduction to the Philosophy of Science, Chicago, London: University of Chicago Press.

18. Ayatollahy, H. (2012), Islamic Philosophical Approach to the Problem of Meaningfulness of Religious Statements, in Pourhasan, G. (ed.), Religious Language and Belief of God, Tehran: Institute for Humanities and Cultural Studies Directions Save, pp. 13-39.

19. Hosseni Sarvary, S.H. (2012), Reviewing the Most Important Theories About Religious Language and the Theory of Natural Language, in Pourhasan, G. (ed.), Religious Language and Belief of God, Tehran: Institute for Humanities and Cultural Studies Directions Save, pp. 83-105.

20. Dinparast, M. (2012), The Basis of Sacred Knowledge in Seyed Hossein Nasr Thoughts, in Pourhasan, G. (ed.), Religious Language and Belief of God, Tehran: Institute for Humanities and Cultural Studies Directions Save, pp. 253-280.

21. Ghafari, H. (2013), The Place of the Philosophy of Religion in the Tradition of Islamic Philosophy According to Avicenna, Philosophy of Religion Research, vol. 10, no. 2, pp. 47-64.

22. Alston, W.P. (1982), Religious experience and religious belief, Noûs, vol. 16, pp. 3-12.

Received: February 19, 2020 Accepted: September 23, 2020

Authors'information:

Massoud Toossi Saeidi — PhD in Philosophy of Religion; masoud.toossi@staff.sharif.edu

Seyed Hassan Hossini — Dr. Sci. in Philosophy, Professor; hoseinih@sharif.ir 


\section{Религиозный язык как естественно-священный язык*}

\section{Масуд Тусси Саейди ${ }^{1}$, Сейед Хасан Хоссини ${ }^{2}$}

${ }^{1}$ Научно-исследовательский институт гуманитарных наук и исследований в области культуры, 14377-74681, Исламская Республика Иран, Тегеран, 64-я ул.

2 Технологический университет Шарифа, 11365-11155, Исламская Республика Иран, Тегеран, ул. Азади

Для цитирования: Massoud Toossi Saeidi, Seyed Hassan Hossini. Religious language as natural-sacred language // Вестник Санкт-Петербургского университета. Философия и конфликтология. 2021. Т. 37. Вып. 1. С. 176-190. https://doi.org/10.21638/spbu17.2021.114

В статье значительное место уделено интерпретации взглядов А.Флю на проблемы религиозного языка. Данная интерпретация показывает, что идеи А. Флю можно воспринимать как критику веры в содержание религиозных утверждений, а не критику их бессмысленности. Если принять такую интерпретацию, становится очевидно, что подход А. Флю не нов и в истории теологической мысли подобные идеи уже высказывались. Кроме того, в статье дан анализ наиболее значимых теорий, касающихся рассматриваемой проблемы, с целью выявления основных постулатов для поиска новых решений. Наша основная идея состоит в том, чтобы объединить две содержащиеся в литературе по вопросу раздельные и противопоставляемые концепции: естественное и священное. Такое объединение может быть начато с понятия естественного языка как теории, взятой из литературы по философии языка. Согласно принципам философии языка, принятым в данной статье, религиозный язык происходит из естественного языка, отличие же его от иных форм в том, что он представляет собой случай специфического использования естественного языка святыми той или иной традиции. Предложив объяснение естественному языку, мы можем в итоге рассматривать святых как использующих естественный язык для повествования о мире сакрального и божественного. Подобно предшествующим мыслителям, рассуждающим о религиозном языке, мы предлагаем собственную аналогию. Представляется полезным сравнить и сопоставить ее с предыдущими, поскольку это позволит прояснить различия и выявить преимущества нового взгляда на проблему религиозного языка. Мы предлагаем новый тип естественного языка, обладающего особой характеристикой.

Ключевые слова: религиозный язык, священное знание, естественный язык, святые, естественно-священный язык.

Статья поступила в редакцию 19 февраля 2020 г.; рекомендована в печать 23 сентября 2020 г.

Контактная информация:

Масуд Тусси Саейди - канд. филос. наук; masoud.toossi@staff.sharif.edu Сейед Хасан Хоссини — д-р филос. наук, проф.; hoseinih@sharif.ir

* Исследование выполнено при финансовой поддержке Национального научного фонда Ирана. 